\title{
Greece and the Aegean in Swedish Archaeology 1986-1990
}

\author{
Gunnel Ekroth
}

\begin{abstract}
This paper constitutes a survey of Swedish scholarship during the period 1986-90 dealing with Greece and the Aegean area from the archaeological viewpoint. A large portion of the work done concerns the Aegean Bronze Age, e.g. aspects of the Minoan palaces, various kinds of pottery, different types of cult, and funerary practices. Scholarship focussed on the Greek Iron Age also shows an inclination towards religious topics, such as the deposition and use of votive offerings in Greek religion and the role of ritual dining, but studies dealing with architecture and pottery may be found as well. The fieldwork and the publication of material from Swedish excavations and surveys are also covered.
\end{abstract}

Gunnel Ekroth, Department of Classical Culture and Ancient Society, Stockholm University, S-10691 Stockholm, Sweden.

Two trends can be defined in the Swedish scholarly activity dealing with Greece and the Aegean during the years 1986-90. As regards periods, there was a focus on various aspects of the Aegean Bronze Age. As regards the topics chosen for study, there seems to have been a special interest in materials and problems dealing with religion, in both the prehistoric and the historic periods. The items commented upon here have been chosen to illustrate these trends and a complete coverage has not been aimed at.

\section{THE MUSEUM OF MEDITERRANEAN} AND NEAR EASTERN ANTIQUITIES

The Museum of Mediterranean and Near Eastern Antiquities in Stockholm closed down for extensive interior re-organisation and was opened again in the summer of 1989. The display has been extensively altered. Preceding the building program was an exhibition entitled "The God with the Double-Axe: Zeus in Labraunda", dealing with the site of Labraunda in Turkey, where
Swedish archaeologists have been active for a long period (on the site itself, see below). The exhibition featured objects from museums in Izmir and Bodrum, Turkey, architectural models of the highly unusual, mixed Doric and Ionic façades of the andron buildings at Labraunda and a relief from the British Museum showing the Carian king Idrieus and his wife Ada. In connection with the exhibition, a catalogue in Swedish was published (Labranda 1987).

In the Bulletin published by the Museum, a few more Greek items were treated. Amnestål (1989) discusses a votive relief showing a man libating in front of an altar. The provenance of the relief is unknown, but Amnestål argues that it belongs to a group of votive reliefs from Mysia, generally dedicated to Zeus. The date is probably the $1 \mathrm{st}$ century BC.

A red-figured cup, entirely black-glazed apart from the tondo, which depicts a man wrapped in his himation and seated on a klismos, is discussed by Hellström (1990b). 
The style is that of a painter related to the group around the Pistoxenos Painter, which dates the cup to around $470 \mathrm{BC}$. The motif is identified as Achilles in retirement, a theme which is likely to have received its pictorial inspiration from the now-lost trilogy Achilleis by Aeschylus, originally based on the Iliad. Hellström suggests that Achilles is shown, not sulking in his tent but mourning the loss of his companion Patroclus. This figure of the serene, solitary Achilles may carry several messages; a reminder of the wars against the Persians, the glory of dying young, and also a homo-erotic theme, making this cup suitable for many contexts in Athenian society, from the symposium to the tomb.

Finally, fragments of a Mycenaean krater (late LH IIIA to early LH IIIB) with a chariot motif are identified by Rystedt as painted by the same hand as a krater in Nauplion and one in Rochester (Rystedt 1988c). Rystedt suggests that the painter should be called the Neck-Bulge Painter, on account of the rendering of a bulge below the necks of the passengers in the chariots. This bulge is to be understood as the horizontally recessed shoulder of the passenger.

\section{REPORTS ON ARCHAEOLOGICAL FIELDWORK AND FINDS FROM EXCAVATIONS}

\section{Berbati}

The Mycenaean settlement at the "Mastos" in the Berbati valley was excavated during the 1930s and 1950s. Among the finds were the remains of Mycenaean pottery production. Publication of the material was planned in two volumes, of which no. 2 has now appeared ( kerström 1987). This study deals with the large amount of Mycenaean pictorial pottery discovered at the site. Pictorial pottery has been found not only on the Greek mainland, but also in Cyprus and in the Near East. The origin of this type of pottery, mainly large, amphoroid kraters, has been widely disputed. The pottery found in the "potters' quarter" at Berbati is very similar to the pictorial pottery found in Cyprus. Åkerström argues that the pottery produced at Berbati was not made for the home market in the Argolid, since very few items of this type have come to light in settlement or grave contexts in this area. More likely the Berbati potters in the LH IIIA-B periods worked for the export trade. The flourishing manufacture at Berbati ceased in the late IIIB period, owing to the changing conditions in the Mycenaean overseas trade and cultural traditions.

The Berbati valley, including the high plateau at Limnes, were also the focus of survey work during the years 1988-90. The aim was to investigate how man used this area and also how the environment made the human occupants adapt to the local conditions, from the Upper Palaeolithic period down to present times. The survey has identified a large number of sites, mainly of small sizes. The majority of these sites have been interpreted as the remains of agricultural activity. A report on the 1988 season has appeared (Wells, Runnels \& Zangger 1990) and the final publication is expected to appear in the imminent future.

The survey has also led to the identification of road systems lined with sites dating from various periods, e.g. Early Helladic, Mycenaean and Classical-Hellenistic (Wells 1990b). Commodities that may have been transported are andesite, obsidian and pottery.

\section{Asine}

Asine in the Middle Helladic period has been treated by G. Nordquist in her dissertation (1987). The study is based on documentation and material from the excavations in the 1920 s, but the results of the investigations in the 1970s are also taken into account. The aim is to present Middle Helladic Asine from as many aspects as possible, e.g. the environmental background, 


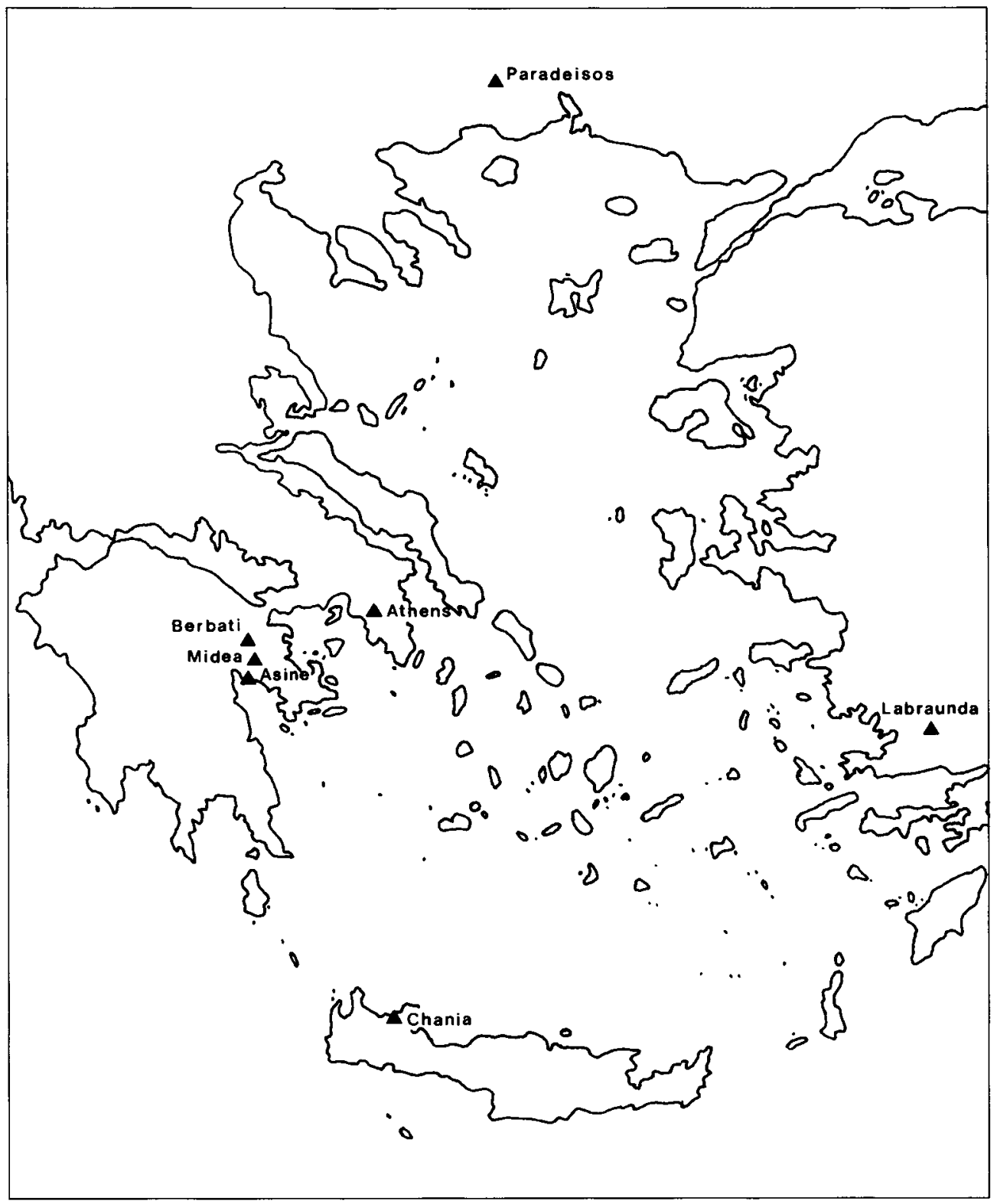

Fig.1. Map of Greece and the Aegean showing the sites where Swedish archaeologists have been active during the period 1986-90.

the setting and planning of the site, the agriculture, the husbandry and the level of technology. The architecture and the mortuary evidence are also discussed, as well as the social structure of the village. Contacts with contemporary sites and areas outside the region are also considered.

A volume treating the Mycenaean re- 
mains from the Karmaniola sector, east of the acropolis, has also appeared. Frizell (1986) has published the habitation remains from this area, which consist mainly of sherd deposits and only a few architectural features. The pottery is very late Mycenaean with an undisputable continuity into the Proto-Geometric. This late Mycenaean phase has been understood and named variously in different parts of Greece. For Asine, Frizell suggests the term "Final Mycenaean" for the phase after LH IIIC and before the Proto-Geometric, in order to avoid the denomination Sub-Mycenaean.

New fieldwork at Asine took place at the Barbouna hill in 1985 (Wells 1988). Beside the fortification wall which runs along the northern slopes of the hill, deposits of Late Geometric pottery (kraters and cups) were found. These deposits have been interpreted as building sacrifices and the wall is thus to be dated to the same period. In 1990, excavation work took place on the Barbouna slope, facing the acropolis, and material dating from the Neolithic to the Roman periods was found. A project has been initiated by B. Wells to fully document the Hellenistic city walls of the Asine acropolis.

Parts of the material found in the excavations in the 1920s are now stored in Uppsala, as well as in Nauplion. Two fragments of a terracotta sima, one kept at each of these two locations, have been discussed by Wells (1990c). The sima originates from the temple of Apollo Pytheos on the Barbouna hill. The earliest temple is dated to the third quarter of the 8th century, but it is known to have been replaced at least in the Archaic period. The sima has close resemblances to a piece from Tiryns, dated to around $500 \mathrm{BC}$, a date also valid for the Barbouna temple. During this period, only scanty traces of activity are known from Asine and there was no proper settlement. This situation fits well with the fact that the sima was not of local manufacture, though probably produced in the Argolid.
Several hundreds of loom-weights dating from the Classical and Hellenistic periods were found in the lower town at Asine in the excavations in the 1920 s and 1930s. Hägg (1990c) discusses around a hundred of these which bear stamped or scratched decorations showing animals, objects like vessels or masks, anthropomorphic figures, letters, stars, palmettes or circles.

A Megarian relief bowl, now housed in the Asine collection at the Gustavianum, Uppsala, has been published by Zehbe (1988). The decoration makes it likely that the bowl was produced in a known workshop at Argos and should be dated between 220 and $150 \mathrm{BC}$.

Among the material from the excavations in the 1920s housed at Uppsala are pieces of slag, found in the lower town. Apparently the slag was discovered together with pottery of mainly Geometric date, bones, shells, etc. Some lumps can be identified as furnace bottoms and broken blast pipes, which are likely to have originated from iron-smelting. Tests will be carried out on this material, in order better to understand this type of activity at Asine (Backe-Forsberg \& Risberg 1986).

\section{Midea}

Swedish excavations were resumed at the acropolis of Midea in the Argolid in 1983 and have since continued on a regular basis (Åström \& Demakopoulou 1986; Åström, Demakopoulou \& Walberg 1988; Åström, Demakopoulou, Divari-Valakou, Fischer \& Walberg 1990). The site was first investigated by the German Archaeological Institute in 1907, by Axel W. Person in 1939 and by a joint Swedish-Greek team in 1963. The new excavations are also a Swedish-Greek collaboration. The site of Midea is well known for its remarkable, Mycenaean, citadel wall, $462 \mathrm{~m}$ long and constructed in Cyclopean technique. Midea suffered destruction in LH IIIB2, most likely due to an 
earthquake. The new excavations have been concentrated on the west and east gates, where remains of houses were recovered. However, Midea was not deserted after the destruction, as LH IIIC material has been found. There are also Middle Helladic traces, as well as thick Roman and Byzantine layers.

\section{Chania}

The work at Chania during the period 198690 was mainly focussed on the analysis of excavated material, e.g. Mycenaean pottery found at the site (Hallager 1988) and only minor excavations were undertaken (e.g. Hallager \& Tzedakis 1986) to clarify problems relating to the LM architecture. In 1989, during a rescue excavation, a spectacular find was made - the first Linear B tablet found on Crete outside Knossos (Hallager, Vlasakis \& Hallager 1990). The fragmentary tablet can be read as " $10+$ pairs of wheels". An interesting connection can be made with the Knossos tablets, since these mention chariots without wheels from Kydonia. Unfortunately, the tablet was found in a rubbish pit and cannot be more accurately dated than in the period LM IIIA:2 to IIIB. However, the find further emphasizes the importance of Chania during Minoan times.

\section{Paradeisos}

In 1976, excavations were undertaken at Paradeisos, north-east of Kavalla in northern Greece (Hellström (ed.) 1987). The site consists of a small hillock located on the western bank of the River Nestos. It was inhabited for the greater part of the 5th millenium BC, i.e. the Late Neolithic period. The inhabitants must have based their subsistence mainly on the herding of cattle and sheep. Pottery was produced, as well as occasional copper tools. The site is in no way spectacular but offers an insight into one of the many, small, farming villages scattered over northern Greece in the
Neolithic period.

\section{Labraunda}

In 1948, Swedish archaeologists began excavating at Labraunda, a site that is unique on account of its well-preserved architecture. The temple has been published previously and recently work has been concentrated on the two andrones used for dining. These buildings do not show the general characteristics of dining-rooms and may also have been connected with the cult or the honouring of the royal couples, Mausollus and Artemisia, and Idrieus and Ada. Hellström (1990a) argues that the architecture of the andrones, featuring a large door-opening, centrally placed on the short wall, and the back wall accentuated by a large niche, can be paralleled at several other sites. These buildings, which at first glance seem like ordinary temples, may also have been used as hestiatoria. In the Hellenistic period, the ritual meal was set in a new context, in which the linkage with the royal power was emphasized. Other buildings at Labraunda have also been connected with ritual dining (Hellström 1989; see below).

\section{THE NEOLITHIC AND BRONZE AGES IN THE AEGEAN}

In 1987, the English archaeologist Colin Renfrew published a study entitled Archaeology and language: The puzzle of the Indo-European origins. He connects the Indo-Europeanization of Europe with the Neolithic revolution, since he believes that a major shift in languages must be connected with a major shift in the material culture as well. Renfrew's thesis, which must be regarded as highly controversial, has led to intense debate. Hellström reviews the study and, though not entirely convinced by Renfrew, he agrees that, if the book stimulates a debate which will further the discussion on the Indo-Europeans, a useful goal will have been reached (Hellström 1990c). For 
the Neolithic site of Paradeisos, see above.

The Aegean Bronze Age is a field in which many Swedish contributions have been made during the last five years. The Swedish interest in this area is also demonstrated by the international symposia and seminars held at the Swedish Institute in Athens. During the period 1986-90, three volumes containing papers from symposia were published: The function of the $\mathrm{Mi}$ noan palaces (Hägg \& Marinatos (eds.) 1987), Early Greek cult practice (Hägg, Marinatos \& Nordquist (eds.) 1988) and Celebrations of death and divinity in the Bronze Age Argolid (Hägg \& Nordquist (eds.) 1990). Papers from a seminar on Early Helladic architecture and urbanization appeared in 1986 (Hägg \& Konsola (eds.) 1986).

A workshop entitled "Trade and production in pre-monetary Greece" was also held at the Swedish Institute in 1990 and the results have been published in Hydra (see, e.g. Schallin 1990 and Sjöberg 1990). Several of the participants were doctoral students presenting parts of forthcoming dissertation work. Schallin (1990) discusses the nature of the Mycenaean presence at the Cyclades, focussing on Phylakopi on Melos. She argues that the Mycenaean finds are better understood as traces of social and religious interaction and the exchange of prestige goods, often related to cult activity, than as indications of regular trade with the mainland. Sjöberg (1990) surveys current economic thinking as applied to the Aegean world and especially the Late Bronze Age society.

The Minoan palaces, especially Knossos, have been the focus of scholarly attention for a period of almost a hundred years. However, many questions still remain unanswered. In a contribution to the symposium on the palaces of Crete, Lindgren reviews the evidence at our disposal for interpreting the function (Lindgren 1987). We have the material remains of the palaces and the Linear A and B texts. Names of places located outside the palaces, known from the texts, may also be used, as well as the geographical and cultural horizon of the world outside Crete. Lindgren suggests possible functions of the palaces as living quarters, workshops, storage accommodation, areas related to cult, and general economic functions.

A major problem in dealing with Minoan architecture seems to be the difficulty in distinguishing between cultic and secular functions. At present there seems to be a general tendency to interpret many of the distinctive characteristics of Minoan architecture as reflections of the religious practices. It is suggested that the west façade of the palaces had an equally important function for the palace as the central court (Hägg 1987b). He presents a new reconstruction, in which this façade is dominated by a wide window, used as a "window of appearance", where persons of religious importance would show themselves to the people gathered in the west court.

A characteristic, Minoan, architectural feature is the so-called lustral basin, a small, sunken area reached by a staircase bent in an angle. As the modern term "lustral basin" suggests, these rooms have been understood as bathrooms in the residential quarters of the palaces. However, they have now been linked to the surrounding architecture more firmly. Nordfeldt (1987) suggests that the lustral basins should be viewed as an architectural unit, together with the polythyron hall (a wall consisting of a pier-and-door arrangement), ante-rooms, light areas and porticos. This architectural unit had a ceremonial character rather than a residential function. Hägg \& Marinatos (1986) argue along the same lines. They view the polythyron as an "area of transit", i.e. it controlled access and allowed the observation of focal points. The doors could be opened or closed to produce sudden light or dark- 
ness. In this dramatic character of Minoan religion, the role of the epiphany, i.e. the divine appearance, was fundamental. Hägg (1986) tries to throw new light on the ritual of anthropomorphic epiphany by linking it to the polythyron and lustral-basin complexes, arguing that the architecture reflects the function. In several of these complexes, the viewers are led in controlled directions around corners, ending up in front of polythyron halls, where the doors could be suddenly opened and the viewers would see a niche or a throne. Hägg assumes that a priestess could have appeared here, acting as the goddess. The whole architecture is constructed with the intention of controlling what was to be seen or not.

In the Throne Room at Knossos were found five alabastron-shaped vessels and some pithos fragments, which have been considered as part of the last phase in the use of the room. Hägg (1988) tries to define more closely the function of the alabastra and concludes that they are likely to have contained perfumed oil or unguent. After reviewing the Minoan and Mycenaean evidence for libations and anointing, he finds that this assemblage has no parallel. The role of libation in Mycenaean cult is further expanded in another paper by Hägg (1990b). This ritual must have been central in Mycenaean religion. The kylix was probably the most common, Mycenaean, libation vessel, but other types of vessels, all with Cretan predecessors, were used as well. Benches incorporating pots or tripod offering-tables served as receptacles for the liquids.

The religious functions of the Minoan palaces may also be reflected in the frescoes. Säflund proposes that some frescoes represent wedding celebrations and that initiation ceremonies ending in a collective marriage, a hieros gammos, may have been performed in the palaces (Säflund 1987).

A group of Cretan terracotta hutmodels, shaped like circular huts with a front door, have been suggested to be representations of simple household shrines dating from the Late Bronze and Early Iron Ages. Hägg argues that the hut-models must represent real buildings, perhaps temporary shrines erected for the goddess to stay in (Hägg 1990a). As several of the models (in all, around 20) are post-palatial, they may be an example of the changing religious manifestations after the decline of the palaces on Crete.

G. Walberg has continued her studies of Minoan pottery, also as compared with other types of Minoan art (Walberg 1986). She has investigated the concepts of tradition and innovation in Minoan art, in order to suggest new viewpoints. She opposes the traditional opinion of Minoan art as close to nature, free and full of dancing movement, and shows that dancing and playing figures form a part of a long, Minoan, artistic tradition. She also discusses the problem of space in Minoan art and the relationship of pottery to glyptic art and fresco-painting. Her conclusion is that Minoan art must be viewed as having been based more on tradition than has been previously thought among scholars and that the innovation that took place was a re-creation within the tradition. Walberg has also dealt with Middle Minoan pottery imported into Egypt and its influences on Egyptian pottery styles, regarding both shapes and decoration (Walberg 1988a). On Crete, the Middle Minoan pottery may occasionally have been imitated in stone, as may be seen in a unique, bridge-spouted jar made of that material (Walberg 1988b).

One of the best-known artifacts of the Middle Minoan period, the so-called Mallia pendant, showing two insects grasping a granulated disc, was re-studied by Björk \& Bloedow (1989). They offer a new interpretation and an explanation which aims at including all the elements of this unique piece of gold jewellery. In their interpretation, the pendant is regarded as an ornament, but 
also as a symbol, understandable to all who saw it. The two insects, identified as bees, symbolize life and the renewal of the Cretan Zeus. The disc carefully displayed by the bees has the shape of a Cretan honeycomb, which is interpreted as the renewal of the kingship to the "Priest-King". Above the heads of the bees is a small cage with a little gold ball which may represent the sun, while the small sphere between the heads of the bees may be understood as a droplet of honey, associated with the nourishing and renewal of Zeus. The pendant must have been worn by a ruler, a hypothesis strengthened by the findspot Chrysolakkos, a tomb complex near the palace at Mallia usually viewed as the royal burial-ground.

Not all Minoan objects were unique and made of precious materials by highly skilled artists. There exists a particular type of small, Minoan, conical cup, which has been found in large numbers at all Minoan or Minoanizing sites. These simple terracotta cups, which have not received much scholarly attention so far, have been studied by Gillis in her dissertation (1990c), as well as in a series of articles. Owing to the large number of cups found, i.e. 550 only from Akrotiri, Thera, the traditional, potteryanalysis approaches cannot be used (Gillis 1990a). Instead, Gillis has employed computer-statistical analyses to deal with the material (Gillis 1990b). Conical cups are known from EM I-II to LM IIIC but are most abundant in MM III to LM I, from which period more than a thousand specimens may occur at a site. The mode of manufacture shows changes from one period to another. In the MM period, the mass production of conical cups began, as can be seen from the traces of production; the cups were thrown from the hump rather than individually, the potter was less careful not to leave fingerprints on the wet clay surface, and cups were occasionally deformed by careless handling when put to dry (Gillis
1988).

Mycenaean pottery is a field of study with special connections with Sweden, mainly through the work of Arne Furumark. At the end of the Mycenaean period, representations of animals, as well as human beings, began to occur on vases. This Pictorial Style has long fascinated scholars but has also given rise to important questions as to the origin of these vases. One site where Mycenaean Pictorial pottery was manufactured was Berbati, but the production may have been intended for export (see Åkerström 1987, above). The motifs of the Pictorial Style, especially the depictions of humans, remain enigmatic. Rystedt (1986) has re-studied twelve Pictorial vases showing silhouette figures on foot. She suggests that the majority of these figures represent runners, owing to the positions of the arms. Some of these runners may be understood as apobatai, i.e. men engaged in a contest in which they jumped on and off wagons, known from historical times in Greece (Rystedt 1988b). Spear-throwers and boxers are also depicted. These interpretations are taken as an indication that athletic contests played a certain role as a Mycenaean vase motif. Another Mycenaean Pictorial motif, a man carrying an object often understood as an oxhide ingot, has been treated by Rystedt (1987). She suggests that these four depictions are better understood as men carrying camp stools of a type found in other, Aegean, Late Bronze Age representations.

Work has also been done in trying to distinguish individual artists in the Pictorial production. The method employed by Rystedt (1990a) is a combination of criteria such as composition, elements of design, single forms and reflections on the temperament of the artist. Rystedt has so far identified four hands and given them names, e.g. the Painter of the Baggy Hooves (Rystedt 1988a) or the Neck-Bulge Painter (Rystedt 1988c). 
Much of our knowledge of the Bronze Age cultures of the Aegean is based on funerary evidence. How this material is to be understood may be a matter for dispute. Nordquist discusses Middle Helladic graves in the Argolid (Nordquist 1990). These graves show great variability in type, furnishings and grave-goods, which is suggested as typical of a small-scale society. However, these variations do not seem to be connected with simple age-groups or the sex of the deceased. For example a simple pit-grave may contain valuable grave-goods, while an elaborate cist-grave may be almost void of gifts, a fact indicating that complicated sets of ideas, as well as various ways of expressing ideals and status, must have affected the burial mode of the Middle Helladic people.

A study of Minoan pottery from Cretan tombs leads Walberg to conclude that similar pottery shapes are found in tombs and sanctuaries, which may reflect similarities in ritual as well (Walberg 1987). There seem to have been no preferences for pots with particular decoration in tombs, and it is likely that most of the pottery found in funerary contexts was not especially manufactured as grave-goods.

From the Mycenaean period, the funerary evidence is even more abundant. A common burial form was the chamber tomb, cut out in bedrock and used for subsequent burials. Wells re-examines various features found in chamber tombs, especially those at Dendra, Argolis (Wells 1990a). The lack of funerary goods may not be wholly explained by looting but may also be due to the intentional removal of objects in Mycenaean times. In some chamber tombs, grooves have been cut at the entrance. Åkerström interprets these grooves as related to the funerary cult (Åkerström 1988), while Wells argues for a relation to the mode of construction.

An important sign of the transition between the Bronze and the Iron Age in
Greece has been considered to be the spread of cremation burials. Hägg (1987c) reviews the evidence for Sub-Mycenaean cremation burials in the Argolid. In this area, inhumation was practised almost exclusively in the Early Iron Age and most of the few cases of cremation remain doubtful or disputed.

\section{GREECE AND THE GREEK WORLD IN CLASSICAL ANTIQUITY}

In the 8 th century, representations of human beings begin to appear on vase-paintings again after a hiatus of more than 300 years. Much of the discussion on the meaning of the motifs of this Late Geometric pottery has centred on whether we here see illustrations of the Homeric epics, other mythological representations or scenes connected with contemporaneous life. A remarkable kantharos in Copenhagen, dated to LG II $a-b$ and found in a grave context, bears depictions of seven scenes; two lions "devouring" a man, women dancing carrying pots on their heads, a single combat, a man and a woman confronting each other, boxing, an acrobatic dance, and Dipylon warriors dancing. Ahlberg-Cornell (1987) suggests that all the scenes can be related to entertainment. There are parallels for Geometric representations, as well as Near Eastern ones, showing circus events, such as the man and the lions are thought to depict. The single combat is understood as a mock combat, and the man and the woman confronting each other is a mimic dance showing the performance of an abduction. The entertainment presented on the kantharos, AhlbergCornell argues, fits the profane sphere better than the occasion of a funeral. Perhaps the kantharos was a prize won in a special performance of just the type depicted on the vase.

Our understanding and reading Geometric, figurative vase-paintings may be facilitated if we understand how the artist worked. Rystedt (1990b) discusses a Late Geometric II krater, trying to understand the artist's 
mode of working.

During the last few decades, much new evidence has come to light regarding Early Greek architecture. Fagerström's dissertation is an attempt to gather and analyse the material available at present (Fagerström 1988b). The changes in society after the end of the Bronze Age led to new types of architecture and the employment of different techniques. Fagerström suggests that in the Late Geometric period the new forms of government and the codification of the law led to a need for meeting-places, which in its turn gave rise to a new architectural phenomenon, the Greek temple. One of the most important Iron Age sites in Greece, Nichoria, located in Messenia, has been treated separately in a paper by Fagerström (1988a).

The dating of various phases and groups of materials from the Early Greek Iron Age is usually achieved by a relative chronology based on archaeological evidence. However, there are a few cases in which Greek material can be related to absolute dates. In his dissertation, Forsberg investigates the possibility of establishing chronologically fixed points for the dating of Greek pottery by its occurrence in Near Eastern destruction layers (Forsberg 1989). The study deals with Samaria and Tarsus, which are usually considered to have been destroyed by the Assyrians in 722 and $696 \mathrm{BC}$ respectively. After reviewing the written and archaeological sources separately, Forsberg concludes that there is no clear evidence for destructions at the two sites at these particular times. Thus, the Greek Iron Age pottery discovered there cannot be used for absolute dating.

Banqueting in Greek sanctuaries is a phenomenon that has received much attention during the last few decades. How to interpret burnt bones, ash and fatty soil at sacrificial sites is discussed by B. Bergquist (1988). It has often been inferred that burntanimal sacrifice formed a part of Bronze
Age sacrifices, mainly owing to the prominent position of this type of sacrifice in the Iron Age cult. Bergquist focusses on two sites with both Bronze and Iron Age remains - Kato Syme on Crete and the sanctuary of Apollon Maleatas at Epidauros. She argues that the burnt bones from the Bronze Age layers originated from sacrificial meals rather than from burnt-animal sacrifices. In the Iron Age, there was a change in cult practice and burnt-animal sacrifices were introduced, probably from the Levant.

Ritual dining may naturally have taken place anywhere in a sanctuary, but many sites have remains of buildings especially designed to house the diners. Hellström has discussed the evidence for this type of activity at the sanctuary of Zeus at Labraunda (Hellström 1989 \& 1990a). At this site are found two large andrones, in which the more prominent participants in the festivities, e.g. the Carian League, may have dined. It is suggested that the oikoi, behind the temple, housed the dining priests, while the large crowd of worshippers must have eaten in tents or other kinds of temporary shelter. A large, still unexcavated complex to the north of the temple may also have contained hestiatoria.

Several buildings have also been reinterpreted as having a function as hestiatoria, e.g. a newly excavated, elongated complex in the sanctuary of Apollo at Halieis in the Argolid. This building has been interpreted by the excavators as a temple, but Bergquist (1990a) has argued that the original function was that of a dining-hall. Proof of the temple function is no earlier than the mid 5th century $\mathrm{BC}$, according to Bergquist. There is no reason to assume that the previous function of the building was identical. The architecture and the finds of the earliest phase (early Archaic) rather point to a function as a hestiatorion.

The Propylaia at the Athenian Acropolis were originally planned to have two wings 
with two rooms in each. Only the north western hall was finally executed and has been interpreted by modern scholars as a dining-hall. Hellström (1988) discusses the function of the originally planned structure with its four halls and suggests that all the rooms were intended to be used for sacred meals in connection with the Panathenaic festival.

Bergquist has also studied the interior spaces of Greek dining-rooms, in order to investigate what spatial arrangements are best adapted to creating a sympotic atmosphere (Bergquist 1990b). Larger or more unusually shaped dining-rooms are likely to have been divided, so that "sympotic subgroups" may have been more easily formed and the communication facilitated.

An important part of Greek religion was the deposition of votive gifts in sanctuaries and shrines. These gifts, often consisting of small and simple figurines of terracotta or bronze, have been found in large numbers at some sites. However, a good deal still remains to be learnt regarding their function, mode of deposition and the choice of a certain type of figurine. Alroth deals with two aspects of votive figurines in her dissertation (1989): the relation between the cult image and the appearance of the figurines, and the presence of figurines showing one deity given to another deity, so-called "visiting gods" (see also Alroth 1987). It seems as if there were no strict rules for the appearance of the dedicated figurines. No figurines can be said to be direct copies of the cult image and thus cannot be used to reconstruct the cult image, which in most cases has not been preserved. As for the occurrence of "visiting gods", this practice can be traced back to the Archaic period but is most frequent in the 5th century BC. "Visiting gods" are found both in large, Panhellenic sanctuaries and in small, local ones. No clear patterns are discernible regarding which deity visited which, but the choice seems rather to have depended on the character of the recipient. In addition, the positioning of votive figurines has been discussed by Alroth (1988).

Another type of votive offering is discussed by Beer (1987). From Cyprus, a group of representations of sitting children, usually called temple-boys, are known. Similar types are found also in Greece and Etruria in sanctuaries. Beer compares the similarities and the differences in the various iconographies, in order to see whether one region may have been influenced by another. She suggests that the iconography was above all developed to suit the purpose, i.e. showing the child in a characteristic pose. The reason for dedicating these statuettes may have varied between the areas but was always connected with wishes for the good health, luck and prosperity of the child.

It has often been assumed that specific types of deities received certain votive offerings that reflected their character as olympian or chthonic. However, many of our notions regarding these distinctions are based on written sources, which may be considerably later than the cults they are applied to. Hägg (1987a) highlights problems that can arise from combining these notions with the archaeological record. His study deals with the question to what extent a votive deposit reflects the kind of deity to whom it was dedicated. Hägg looks into the votive deposits from three sites identified as being those of hero-cults, in order to see whether the assemblage can be said to have a "heroic character" or not. His conclusions are that the individual objects do not seem to be exclusive to a particular type of cult, but the composition is. In this early period, Late Geometric to early Archaic, there seem to have been no clear-cut divisions between the votive practices of funerary ceremonies, the cult of the ancestors and the cult of the heroes. Thus, the distinction between olympian and chthonic is less clear in the archaeological record than in the 
written sources.

Architectural terracottas have recently started to receive an increasing amount of scholarly attention. Even the plain roof-tiles are now beginning to be investigated. An important event was a conference on rooftiles held at the American School of Classical Studies in Athens in 1988. In a contribution to this conference, Wikander discussed the problems surrounding the occurrence of terracotta roofs in the Archaic period (Wikander 1990). From the period $700-650 \mathrm{BC}$ only a handful of tiled roofs are known from a restricted area in Greece. These early tiles all originate from temples, the earliest of which seems to be the temple of Apollo at Corinth $(680 \mathrm{BC})$. During the period 650-600, a complete change took place, and tiled roofs are found at sites over most of the Hellenized world. The reason why tiled roofs began to be employed is explained by Wikander as an answer to the fire hazard, especially apparent at temple sites at which there were large altars with blazing fires. The rapid urbanization, with increased risks of fires, led to a wider use of roof-tiles. It is suggested that the shape of the tiles was due to a transference of the basic, overlapping structure of wooden shingles rather than a heritage from Mycenaean forerunners. Various types of plain roof-tiles, as well as tiles with special functions, e.g. for the eaves and gables of saddle-roofs, hip-roofs and apses, have also been commented upon by Wikander (1988).

The similarities between four Archaic buildings located in Greece and Italy are discussed by Scheffer (1990). Building F on the Athenian Agora has a plan reminiscent of the Regia on the Forum Romanum, as well as of building complexes in Aquarossa and in Satricum. All four buildings have a residential character but differ from ordinary houses in size, planning and location. Scheffer suggests that the construction techniques and the angular plan were introduced into Etruria by Greek architects and builders.

A large number of the preserved, Attic, black-and-red-figure vases have been found outside Greece, predominantly in Etruscan graves in Italy. Scheffer discusses the question to what extent the Athenian potters and painters who produced blackfigure vessels in the second half of the 6th century were aware that their products were to be sold abroad (Scheffer 1988b). She concludes that it is likely that, during this period, the painters must have known that a very high percentage of their work was to be exported and that this may have affected the choice of motif, at least in some cases. However, the shape seems to have been a more important trade factor than the motif. Sets of imported drinking vessels found in Etruscan graves seem to have been a prestigious funerary gift. Whether the drinking sets were equally important in daily life can only be a matter of speculation, since so few Etruscansettlement contexts are known.

A black-figure vase-painter called the Red-Line Painter is the focus of a study by Holmberg (1990). This painter was active around $510-475 \mathrm{BC}$ and a total of 118 vases have been connected with him. Holmberg suggests that only a minority of these were painted by the master himself and that the rest were produced by his workshop staff. Favourite motifs are Hercules and Dionysus in various situations. The Red-Line Painter was probably also a potter, which may explain the fact that he decorated the same type of vases for almost thirty years and also the inferior quality of his painting.

Two particular, pottery motifs are commented upon by Scheffer. Depictions of marine fauna are quite rare, occurring mainly as complementary decoration in both Attic, Corinthian, Lakonian and Etruscan vase-painting (Scheffer 1988a). Skyphoi decorated with a gorgoneion have been thoroughly studied by a German 
scholar. Scheffer (1986) adds four more skyphoi to the series and suggests that they were produced by two hands rather than one and maybe in two interacting workshops, one of which produced for Attica,

\section{REFERENCES}

Ahlberg-Cornell, G. 1987 (pr. 1988). Games, play and performance in Greek Geometric art. The kantharos Copenhagen NM 727 reconsidered. Acta Archaeologica 58:55-86.

Åkerström, Å. 1987. Berbati. Vol.2. The pictorial pottery (Skrifter utgivna av Svenska Institutet $i$ Athen, $\left.4^{\circ}, 36: 2\right)$. Stockholm.

- 1988. Cultic installations in Mycenaean rooms and tombs. In: E.B. French \& K. Wardle (eds.). Problemsin GreekPrehistory. Paperspresented at the centenary conference of the British School of Archaeology at Athens, Manchester, April 1986, Bristol, 201-210.

Alroth, B. 1987. Visiting gods - who and why? In: T. Linders \& G. Nordquist (eds.). Gifts to the gods. Proceedings of the Uppsala symposium 1985 (Boreas, 15), Uppsala, 9-19.

- 1988. The positioning of Greek votive figurines. In: R. Hägg, N. Marinatos \& G. Nordquist (eds.). Early Greek cult practice. Proceedings of the fifth International Symposium at the Swedish Institute at Athens, 26-29 June, 1986 (Skrifter utgivna av Svenska Institutet $i$ Athen, $4^{\circ}, 38$ ), Stockholm, 195-203.

-1989. Greek gods and figurines: Aspects of the anthropomorphic dedications (Boreas, 18). Diss. Uppsala.

Amnestål, L. 1989. A votive relief in Stockholm. Medelhavsmuseet Bulletin 24:19-30.

Åström, P. \& Demakopoulou, K. 1986. New excavations in the citadel of Midea, 19831984. Opuscula Atheniensia 16:19-25.

Åström, P. Demakopoulou, K. \& Walberg, G. 1988. Excavations in Midea, 1985. Opuscula Atheniensia 17:7-11.

Åström, P., Demakopoulou, K., Divari-Valakou, N., Fischer, P. \& Walberg, G. 1990. Excavations in Midea, 1987. Opuscula Atheniensia 18:9-22.

Backe-Forsberg, Y. \& Risberg, C. 1986. Metalworking at Asine. "New" finds from the 1926 season. Opuscula Atheniensia 16:123-125. while the other concentrated more on export.

English revised by Neil Tomkinson.

Beer, C. 1987. Comparative votive religion: The evidence of children in Cyprus, Greece and Etruria. In: T. Linders \& G. Nordquist (eds.). Gifts to the gods. Proceedings of the Uppsala symposium 1985 (Boreas, 15), Uppsala, 21-29.

Bergquist, B. 1988. The archaeology of sacrifice: Minoan versus Greek. A brief query into two sites with contrary evidence. In: R. Hägg, N. Marinatos \& G. Nordquist (eds.). Early Greek cult practice. Proceedings of the fifth International Symposium at the Swedish Institute at Athens, 26-29 June, 1986 (Skrifter utgivna av Svenska Institutet i Athen, $\left.4^{\circ}, 38\right)$, Stockholm, 21-24.

- 1990a. Primary or secondary temple function: The case of Halieis. Opuscula Atheniensia 18: 23-27.

- 1990b. Sympotic space: A functional aspect of Greek dining rooms. In: O. Murray (ed.). Sympotica. A symposium on the symposion, Oxford, 37-65.

Björk, C. \& Bloedow, E. F. 1989. The Mallia pendant: A study in iconography and Minoan religion. Studi micenei ed egeo-anatolici 27:9-67.

Fagerström, K. 1988a. Finds, function and plan: A contribution to the interpretation of Iron Age Nichoria in Messenia. Opuscula Atheniensia 17:33-50.

- 1988b. Greek Iron Age architecture. Developments through changing times (Studies in Mediterranean Archaeology, 81). Diss. Gothenburg.

Forsberg, S. 1989. Near Eastern destruction datings as sources for Greek and Near Eastern Iron Age chronology. Archaeologicalhistorical studies 1 . The cases of Samaria $(722$ B.C.) and Tarsus (696 B.C.). Diss. Uppsala.

Frizell (Santillo), B. 1986. Asine II. Results of the excavations east of the acropolis 1970-1974. Fasc. 3. The Late and Final Mycenaean periods (Skrifter utgivna av Svenska In- 
stitutet i Athen, $\left.4^{\circ}, 24: 3\right)$. Stockholm.

Gillis, C. 1988. Production and society. In: J. Christiansen \& T. Melander (eds.). Ancient Greek and related pottery. Proceedings of the 3rd symposium, Copenhagen, August 31-September 4, 1987, Copenhagen, 186194.

- 1990a. Akrotiri and its neighbours to the south: Conical cups again. In: D.A. Hardy (ed.). Thera and the Aegean world III. Proceedings of the third international congress. Santorini, Greece, 3-9 September 1989, Vol. 1: Archaeology, London, 98-117.

- 1990b. Statistical analyses and conical cups. A preliminary report from Akrotiri, Thera. Opuscula Atheniensia 18:63-93.

- 1990c. Minoan conical cups. Form, function and significance (Studies in Mediterranean Archaeology, 89). Diss. Gothenburg.

Hägg, R. 1986. Die göttliche Epiphanie. Athenische Mitteilungen 101:10-18.

- 1987a. Gifts to the heroes in Geometric and Archaic Greece. In: T. Linders \& G. Nordquist (eds.). Gifts to the gods. Proceedings of the Uppsala symposium 1985 (Boreas, 15), Uppsala, 93-99.

- 1987b. On the reconstruction of the west façade of the palace at Knossos. In: R. Hägg \& N. Marinatos (eds.). The function of the Minoan palaces. Proceedings of the fourth International Symposium at the Swedish Institute in Athens, 10-16 June, 1984 (Skrifter utgivna av Svenska Institutet $i$ Athen $, 4^{\circ}, 35$ ), Stockholm, 129-134.

- 1987c. Submycenaean cremation burials in the Argolid? In: R. Laffineur (ed.). Thanatos. Les coutumes funéraires en Égée à l'âge du bronze. Actes du colloque de Liège (21-23 avril 1986) (Aegeum, 1), Liège, 207-212.

- 1988. The last ceremony in the throne room at Knossos. Opuscula Atheniensia 17:99-105.

- 1990a. The Cretan hut-models. Opuscula Atheniensia 18:95-107.

- 1990b. The role of libations in Mycenaean ceremony and cult. In: R. Hägg \& G.C. Nordquist (eds.). Celebrations of death and divinity in the Bronze Age Argolid. Proceedings of the sixth International Symposium at the Swedish Institute at Athens, 11-13 June, 1988 (Skrifter utgivna av Svenska Institutet $i$ Athen, $4^{\circ}, 40$ ), Stockholm, 177-184.

- 1990c. Gestempelte Webgewichte aus Asine. In:
Akten des XIII. internationalen Kongresses für klassiche Archäologie, Berlin 1988, Mainz, 404.

Hägg, R. \& Konsola, D. 1986 (eds.). Early Helladic architecture and urbanization. Proceedings of a seminar held at the Swedish Institute in Athens, June 8, 1985 (Studies in Mediterranean Archaeology, 76). Gothenburg.

Hägg, R. \& Marinatos, N. 1986. On the ceremonial function of the Minoan polythyron. Opuscula Atheniensia 16:57-73.

Hägg, R. \& Marinatos, N. 1987 (eds.). The function of the Minoan palaces. Proceedings of the fourth International Symposium at the Swedish Institute in Athens, 10-16 June, 1984 (Skrifter utgivna av Svenska Institutet $i$ Athen, $4^{\circ}, 35$ ). Stockholm.

Hägg, R., Marinatos, N. \& Nordquist, G. 1988 (eds.). Early Greek cult practice. Proceedings of the fifth International Symposium at the Swedish Institute at Athens, 26-29 June, 1986 (Skrifter utgivna av Svenska Institutet $i$ Athen, $\left.4^{\circ}, 38\right)$. Stockholm.

Hägg, R. \& Nordquist, G. C. 1990 (eds.). Celebrations of death and divinity in the Bronze Age Argolid. Proceedings of the sixth International Symposium at the Swedish Institute at Athens, 11-13 June, 1988 (Skrifter utgivna av Svenska Institutet $i$ Athen $\left.4^{\circ}, 40\right)$. Stockholm.

Hallager (Pålsson), B. 1988. Mycenaean pottery in LM III Al deposits at Khania, western Crete. In: E. B. French \& K. Wardle (eds.). Problems in Greek Prehistory. Papers presented at the centenary conference of the British School of Archaeology at Athens, Manchester, April 1986, Bristol, 173-183.

Hallager, E. \& Tzedakis, Y. 1986 (pr. 1990). The Greek-Swedish excavations at Kastelli, Khania 1987. Athens Annals of Archaeology 19:11-26.

Hallager, E., Vlasakis, M. \& Hallager, B.P. 1990. The first Linear B tablet(s) from Khania. Kadmos 29:24-34.

Hellström, P. 1987 (ed.). Paradeisos. A Late Neolithic settlement in Aegean Thrace (Medelhavsmuseet Memoir, 7). Stockholm.

- 1988. The planned function of the Mnesiklean Propylaia. Opuscula Atheniensia 17:107-121. - 1989. Formal banqueting at Labraunda. In:T. Linders \& P. Hellström (eds.). Architecture and society in Hecatomnid Caria. Symposium at 
Uppsala, 22-25 October 1987 (Boreas, 17), Uppsala, 99-104.

- 1990a. Hellenistic architecture in the light of late Classical Labraunda. In: Akten des XIII. internationalen Kongresses für klassiche Archäologie, Berlin 1988, Mainz, 243-252.

-1990b. Achilles in retirement. Medelhavsmuseet Bulletin 25:19-31.

- 1990c. Indoeuropéerna åter på vandring. Fornvännen:124-128 (review of C. Renfrew, Archaeology and language. The puzzle of the Indo-European origins. London 1987).

Holmberg, E. 1990. The Red-line painter and the workshop of the Acheloos painter (Studies in Mediterranean Archaeology, Pocketbook 87). Jonsered.

Labranda 1987. Guden med dubbelyxan. Zeus $i$ Labranda. 10 okt 1987-10 jan 1988 (Medelhavsmuseet Skrifter, 9). Stockholm.

Lindgren, M. 1987. The function of the Minoan palaces: Myth and reality. In: R. Hägg \& N. Marinatos (eds.). The function of the Minoan palaces. Proceedings of the fourth International Symposium at the Swedish Institute in Athens, 10-16 June, 1984 (Skrifter utgivna av Svenska Institutet i Athen, $\left.4^{\circ}, 35\right)$, Stockholm, 39-42.

Nordfeldt, A.-C. 1987. Residential quarters and lustral basins. In: R. Hägg \& N. Marinatos (eds.).The function of the Minoan palaces. Proceedings of the fourth International Symposium at the Swedish Institute in Athens, 10-16 June, 1984 (Skrifter utgivna av Svenska Institutet $i$ Athen $\left.4^{\circ}, 35\right)$, Stockholm, 39-42.

Nordquist, G. 1987. A Middle Helladic village. Asine in the Argolid (Boreas, 16). Diss. Uppsala.

- 1990. Middle Helladic burial rites: Some speculations. In: R. Hägg \& G.C. Nordquist (eds.). Celebrations of death and divinity in the Bronze Age Argolid. Proceedings of the sixth International Symposium at the Swedish Institute at Athens, 11-13 June, 1988 (Skrifter utgivna av Svenska Institutet $i$ Athen, $4^{\circ}$, 40), Stockholm, 35-41.

Rystedt, E. 1986. The foot-race and other athletic contests in the Mycenaean world. The evidence of the pictorial vases. Opuscula Atheniensia 16:103-116.

- 1987. Oxhide ingots or camp stools? Notes on a motif in Mycenaean pictorial vase-painting. Report of the Department of Antiquities, Cyprus, 49-55.

- 1988a. Bastard animals on a Mycenaean krater in London. Report of the Department of Antiquities, Cyprus, 267-270.

- 1988b. Mycenaean runner - including Apobatai. In: E.B. French \& K. Wardle (eds.). Problems in Greek Prehistory. Papers presented at the centenary conference of the British School of Archaeology at Athens, Manchester, April 1986, Bristol, 437-442.

- 1988c. New light on a Mycenaean pictorial vase painter. Medelhavsmuseet Bulletin 23:21-32.

- 1990a. On distinguishing hands in Mycenaean pictorial vase-painting. Opuscula Atheniensia 18:167-176.

- 1990b. Die Wagenfriese der attischen geometrischen Keramik und die Frage ihrer Ablesung. Vorläufige Bemerkungen einer Vase im Louvre. Opuscula Atheniensia 18: 177-183.

Säflund, G. 1987. The agoge of the Minoan youth as reflected by palatial iconography. In: $\mathrm{R}$. Hägg \& N. Marinatos (eds.). The function of the Minoan palaces. Proceedings of the fourth International Symposium at the Swedish Institute in Athens, 10-16 June, 1984 (Skrifter utgivna av Svenska Institutet $i$ Athen, $4^{\circ}, 35$ ), Stockholm, 227-233.

Schallin, A.-L. 1990. The nature of the finds from Phylakopi. Hydra 7:49-51.

Scheffer, C. 1986. Some further comments on the gorgoneion skyphoi. OpusculaAtheniensia 16: 117-122.

- 1988a. Marine fauna: An unusual motif in Athenian black figure. Opuscula Atheniensia 17:231-234.

- 1988b. Workshop and trade patterns in Athenian black figure. In: J. Christiansen \& T. Melander (eds.). Ancient Greek and related pottery. Proceedings of the 3rd symposium, Copenhagen, August 31-September 4, 1987 , Copenhagen, 536-546.

- 1990. "Domus Regiae" - a Greek tradition? Opuscula Atheniensia 18:185-191.

Sjöberg, B.L. 1990. The Mycenaean economy: Theoretical frameworks. Hydra 7:59-75.

Walberg, G. 1986. Tradition and innovation: Essays in Minoan art. Mainz.

- 1987. Early Cretan tombs: The pottery. In: R. Laffineur (ed.). Thanatos. Les coutumes funé- 
raires en Égée àl'âge du bronze. Actes du colloque de Liège (21-23 avril 1986)(Aegeum, 1), Liège,53-60.

- 1988a. Kamares imitations in Egypt and their social and economic implications. In: J. Christiansen \& T. Melander (eds.). Ancient Greek and related pottery. Proceedings of the 3rd symposium, Copenhagen, August 31 September 4, 1987, Copenhagen, 633-639.

- 1988b. Relationships between Kamares and Minoan stone vases. Antike Kunst 31:3-4.

Wells, B. 1988. Early Greek building sacrifices. In: R. Hägg, N. Marinatos \& G. Nordquist (eds.). Early Greek cult practice. Proceedings of the fifth International Symposium at the Swedish Institute at Athens, 26-29 June, 1986 (Skrifter utgivna av Svenska Institutet $i$ Athen, $4^{\circ}, 38$ ), Stockholm, 259 . 266.

- 1990a. Death at Dendra. On mortuary practices in a Mycenaean community. In: R. Hägg \& G. C. Nordquist (eds.). Celebrations of death and divinity in the Bronze Age Argolid. Proceedings of the sixth International Symposium at the Swedish Institute at Athens, 11-13 June, 1988 (Skrifter utgivna av Svenska Institutet $i$ Athen, $4^{\circ}, 40$ ), Stockholm, 125-140.

- $1990 \mathrm{~b}$. Trade routes in north-east Argolis. Hydra 7:87-91.

- 1990c. The Asine sima. In: N. Winter (ed.). Proceedings of the first international conference on Archaic Greek architectural terracottas, December 2-4, 1988 (= Hesperia 59:1, 1990), Princeton, 157-161.

Wells, B., Runnels, C. \& Zangger, E. 1990. The Berbati-Limnes archaeological survey. The 1988 season. Opuscula Atheniensia 18:207238.

Wikander, Ö. 1988. Ancient roof-tiles: Use and function. Opuscula Atheniensia 17:203-216.

- 1990. Archaic roof tiles: The first generations. In: N. Winter (ed.). Proceedings of the first international conference on Archaic Greek architectural terracottas, December 2-4, 1988 (= Hesperia 59:1, 1990), Princeton, 285-290.

Zehbe, I. 1988. Ein Megarischer Reliefbecher von Asine. Opuscula Atheniensia 17:217-224. 